\title{
KAJIAN FAKTOR PENENTU SURPLUS (DEFISIT) UNDERWRITING DANA TABARRU' PADA PERUSAHAAN ASURANSI UMUM SYARIAH DAN UNIT USAHA SYARIAH PERUSAHAAN ASURANSI UMUM DI INDONESIA
}

\author{
Novi Puspitasari, Amalia Nurfarida, Lilik Farida \\ Universitas Jember \\ Email: novipuspitasari@unej.ac.id
}

\begin{abstract}
ABSTRAK
Tujuan penelitian ini adalah menganalisis pengaruh klaim, retakaful, hasil investasi, dan kontribusi peserta terhadap surplus (defisit) underwriting dana tabarru' pada perusahaan asuransi umum syariah dan unit usaha syariah perusahaan asuransi umum di Indonesia. Metode purposive sampling digunakan untuk penentuan sampel penelitian ini. Populasi yang diperoleh berjumlah 26 perusahaan asuransi umum syariah dan unit usaha syariah, yang kemudian diperoleh 10 sampel perusahaan yang sesual kriteria. Metode analisis data yang digunakan dalam penelitian ini adalah analisis regresi linear berganda. Hasil penelitian menunjukkan bahwa klaim berpengaruh negatif dan signifikan terhadap surplus (defisit) underwriting dana tabarru', retakaful dan hasil investasi tidak berpengaruh signifikan terhadap surplus (defisit) underwriting dana tabarru', dan kontribusi peserta berpengaruh positif dan signifikan terhadap surplus (defisit) underwriting dana tabarru'.
\end{abstract}

Kata Kunci: Hasil investasi, klaim, kontribusi peserta, retakaful, surplus (defisit) underwriting dana tabarru'

\section{PENDAHULUAN}

Indonesia menganut dual sistem ekonomi, yaitu ekonomi konvensional dan ekonomi Syariah. Hal ini menjadikan layanan jasa keuangan juga menggunakan dua sistem, salah satunya pada asuransi. Terdapat 2 kelompok sistem asuransi yaitu asuransi dengan sistem konvensional dan asuransi dengan sistem syariah. Asuransi syariah lahir dari ketentuan Islam dan secara garis besar merupakan asuransi yang berdasarkan hukum Islam dimana dalam hukumnya sudah ditentukan kondisi wajib, sunnah, halal, makruh dan haram. Secara definisi asuransi syariah adalah usaha saling melindungi dan tolong menolong diantara sejumlah orang melalui investasi dalam bentuk asset dan/atau tabarru' yang memberikan pola pengembalian untuk menghadapi resiko tertentu melalui akad yang sesuai dengan syariah (DSN MUI, 2002).

Asuransi Syariah terbagi dalam dua kelompok yaitu asuransi syariah keluarga (asuransi jiwa) dan asuransi umum syariah. Asuransi syariah keluarga (asuransi jiwa) merupakan bentuk asuransi yang memberikan perlindungan dalam menghadapi musibah kematian dan kecelakaan atas diri asuransi. Sedangkan asuransi umum syariah merupakan bentuk asuransi yang memberi perlindungan dalam menghadapi bencana atau kecelakaan harta milik peserta asuransi seperti rumah, kendaraan bermotor, dan bangunan pabrik (Manan, 2012:271). Jumlah asuransi syariah per juli 2018 mencapai 13 unit industri syariah dan 50 unit usaha syariah, dengan rincian yaitu asuransi jiwa syariah terdiri dari 7 unit industri syariah dan 23 unit 
usaha syariah, asuransi umum syariah terdiri dari 5 unit industri syariah dan 25 unit usaha syariah, serta reasuransi syariah terdiri dari 1 unit industri syariah dan 2 unit usaha syariah (Statistik Bulanan IKNB Syariah, 2018).

Akad yang digunakan dalam asuransi umum syariah adalah akad tabarru' (akad hibah) dan akad wakalah bil ujrah. Penggunaan kedua akad tersebut merupakan fatwa Dewan Syariah Nasional Majelis Ulama Indonesia (DSN MUI). Akad tabarru' adalah akad yang bertujuan untuk kebaikan dan tidak untuk mencari keuntungan. Sedangkan akad wakalah bil ujrah adalah jenis akad tijarah yaitu akad yang digunakan untuk bisnis bersifat komersil (mencari keuntungan).

Jadi, dalam asuransi umum syariah pada saat pembayaran kontribusi didasarkan pada kedua akad tersebut. Kontribusi yang dibayarkan peserta atau nasabah terdiri dari dana tabarru' yang didasarkan pada akad tabarru' dan dana ujrah yang didasarkan pada akad wakalah bil ujrah. Dana tabarru' dikumpulkan dalam satu akun khusus dimana hanya ada kumpulan dana peserta tabarru', dan ini tidak boleh digunakan untuk kebutuhan lain khusus diberikan kepada peserta atau nasabah untuk dana tolong menolong dan suka rela. Sehingga secara otomatis dana tabarru' menjadi aset kelompok peserta dana tabarru' tersebut (DPT). Sedangkan dana ujrah merupakan dana hasil dari jasa pengelolaan dana tabarru' peserta, dimana dana ini berupa fee atau upah yang diberikan kepada perusahaan asuransi umum syariah. Dana ujrah ini merupakan milik perusahaan yang dapat digunakan untuk biaya operasional perusahaan dan secara otomatis menjadi aset dana pemegang saham (DPS) (Puspitasari, 2012).
Dalam proses operasionalnya, perusahaan asuransi syariah tidak lepas dari penerapan fungsi manajemen underwriting. Underwriting merupakan proses penyelesaian risiko dan mengklarifikasikannya sesuai dengan tingkat yang dapat ditanggung oleh perusahaan. Dalam hal ini, risiko yang muncul adalah klaim yang mungkin akan dihadapi oleh perusahaan asuransi di masa yang akan datang (Damayanti, 2016). Menurut fatwa DSN MUI No. 21/DSN-MUI/X/20001 tentang Pedoman Umum Asuransi Syariah, klaim adalah hak peserta asuransi yang wajib diberikan oleh perusahaan asuransi sesuai dengan kesepakatan dalam akad.

Bisnis asuransi umum syariah juga tidak akan lepas dari kegiatan retakaful. Pada bisnis asuransi umum syariah, kegiatan retakaful sangat penting dan pasti dilakukan pada saat perusahaan asuransi umum syariah menerima peserta dengan memiliki tingkat risiko yang dianggap besar dan perusahaan asuransi umum syariah tidak mampu untuk menanggulanginya sendiri. Bagi perusahaan asuransi umum syariah, semakin besar kontribusi retakaful yang dibayarkan menunjukkan semakin tinggi risiko yang melekat pada objek yang diasuransikan sehingga membutuhkan dana tabarru' yang semakin besar. Kegiatan retakaful harus benar-benar diperhitungkan karena tingginya frekuensi pembayaran kontribusi retakaful akan mengurangi proporsi cadangan klaim bagi peserta perusahaan asuransi umum syariah serta berkurangnya porsi untuk investasi. Kondisi ini dikhawatirkan akan memengaruhi menurunnya atau bahkan tidak adanya surplus underwriting. Surplus underwriting yang rendah akan berpengaruh jumlah pengembalian surplus dana peserta tabarru' yang akan dibagikan kepada stakeholders yang 


\section{$\mathrm{JOPBA}$}

berkontribusi pada keberadaan dana peserta tabarru', cadangan tabarru', dan perusahaan pengelola (Puspitasari, 2015:217).

Berdasarkan latar belakang tersebut, maka rumusan masalah dalam penelitian ini yaitu apakah klaim, retakaful, hasil investasi, dan kontribusi peserta berpengaruh terhadap underwriting pengelolaan dana tabarru' pada perusahaan asuransi umum syariah dan unit usaha syariah perusahaan asuransi umum di Indonesia. Sedangkan tujuan dari penelitian ini yaitu untuk menganalisis faktor-faktor yang berpengaruh terhadap underwriting pengelolaan dana tabarru' pada perusahaan asuransi umum syariah dan unit usaha syariah perusahaan asuransi umum di Indonesia.

\section{METODE PENELITIAN Rancangan Penelitian}

Penelitian ini merupakan penelitian kuantitatif dengan jenis penelitian eksplanatori yang dilakukan terhadap laporan keuangan Perusahaan Asuransi Umum Syariah dan Unit Usaha Syariah Perusahaan Asuransi Umum di Indonesia pada periode tahun 2013-2017.

\section{Populasi dan Sampel}

Populasi dalam penelitian ini adalah Perusahaan Asuransi Umum Syariah dan Unit Usaha Syariah Perusahaan Asuransi Umum di Indonesia yang terdaftar di Otoritas Jasa Keuangan dalam kurun waktu 2013-2017. Populasi yang diperoleh yaitu sebanyak 26 perusahaan asuransi umum syariah dan unit usaha syariah, yang kemudian diperoleh 10 sampel perusahaan yang sesuai dengan kriteria. Teknik pengambilan sampel yang digunakan adalah purposive sampling.
ISSN-E : XXX

ISSN-P : XXX

\section{Jenis dan Sumber Data}

Jenis data yang digunakan dalam penelitian ini berupa data sekunder, yaitu laporan keuangan tahunan Perusahaan Asuransi Umum Syariah dan Unit Usaha Syariah Perusahaan Asuransi Umum di Indonesia yang terdaftar di Otoritas Jasa Keuangan dalam kurun waktu 2013-2017. Sumber data penelitian ini diperoleh dari laman resmi Otoritas Jasa Keuangan dan laman website dari masing-masing perusahaan yang menjadi sampel penelitian, serta sumber data lainnya yang didapatkan dari beberapa literatur buku dan jurnal penelitian terdahulu yang sesuai dengan kebutuhan penelitian.

\section{Metode Analisis Data}

Metode analisis data dalam penelitian ini yaitu menggunakan uji normalitas data, analisis regresi linear berganda, uji asumsi klasik, dan uji hipotesis (uji t). Uji normalitas data digunakan untuk menguji bahwa data setiap variabel penelitian yang akan dianalisis membentuk distribusi normal atau tidak. Analisis regresi linear berganda digunakan untuk mengetahui pengaruh antara variabel independen terhadap variabel dependen. Uji asumsi klasik digunakan untuk menguji terjadinya kesalahan pengujian pada variabel dengan model regresi. Sedangkan uji hipotesis (uji t) digunakan untuk menguji secara parsial pengaruh masing-masing variabel independen yang digunakan.

\section{HASIL PEMBAHASAN Gambaran Umum Objek Penelitian}

Populasi dalam penelitian ini berjumlah 26 perusahaan yang terdiri dari 3 perusahaan asuransi umum syariah dan 23 unit usaha syariah perusahaan asuransi umum. Sedangkan berdasarkan teknik pengambilan sampel, sampel yang diambil dalam penelitian ini yaitu sebanyak 10 perusahaan yang 


\section{$\mathrm{JOPBA}$}

mempublikasikan laporan keuangan secara konsisten dari tahun 2013-2017 atau sebanyak 50 laporan keuangan. Tabel 4.1 menyajikan sampel penelitian. Lampiran 2 menyajikan profil perusahaan populasi dan sampel penelitian.

Tabel 4.1 Sampel Penelitian

\begin{tabular}{llc}
\hline No & \multicolumn{1}{c}{ Keterangan } & Jumlah \\
\hline $1 . \quad$ Jumlah perusahaan & 26 \\
asuransi umum syariah & \\
dan unit usaha syariah & \\
perusahaan asuransi & \\
umum yang terdaftar \\
di Otoritas Jasa \\
Keuangan \\
2erusahaan yang tidak \\
konsisten \\
mempublikasikan \\
laporan keuangannya \\
Perusahaan yang \\
belum melakukan \\
konsep pemisahan \\
dana sesuai dengan \\
Peraturan \\
Keuangan Menteri \\
\hline No \\
\hline Sampeterangan Penelitian \\
\hline Jumlah Data Pengamatan \\
(10 x 5 Tahun)
\end{tabular}

Sumber : data diolah
ISSN-E : XXX

ISSN-P : XXX

\section{Deskripsi Statistik Data}

Tabel 4.2 Deskripsi Statistik Data

\begin{tabular}{|c|c|c|c|c|}
\hline Variabel & $\begin{array}{c}\text { Nilai } \\
\text { Minim } \\
\text { um }\end{array}$ & $\begin{array}{c}\text { Nilai } \\
\text { Maksi } \\
\text { mum }\end{array}$ & $\begin{array}{c}\text { Nilai } \\
\text { Rata-ra } \\
\text { ta }\end{array}$ & $\begin{array}{l}\text { Deviasi } \\
\text { Standar }\end{array}$ \\
\hline SDUT $(\%)$ & $-0,21$ & 2,33 & 0,2520 & 0,38717 \\
\hline Klaim (\%) & $-87,69$ & 65,82 & 9,3284 & 27,85946 \\
\hline Retakaful (\%) & $-184,75$ & 52,62 & $-12,1046$ & 37,24186 \\
\hline $\begin{array}{l}\text { Hasil investasi } \\
(\%)\end{array}$ & $-28,53$ & 11,14 & 1,6876 & 5,07279 \\
\hline $\begin{array}{l}\text { Kontribusi } \\
\text { peserta (Juta Rp) }\end{array}$ & -6.321 & 60.910 & 1,52 & $17.775,177$ \\
\hline
\end{tabular}

Deskripsi statistik data penelitian terangkum dalam Tabel 4.2. Pada Tabel 4.2, variabel SDUT memiliki nilai rata-rata sebesar $0,25 \%$ dan deviasi standar sebesar $0,38 \%$. Nilai deviasi standar yang lebih besar dari nilai rata-rata menunjukan bahwa surplus (defisit) underwriting dana tabarru' perusahaan yang menjadi sampel penelitian sangat bervariasi. Nilai minimumnya yaitu sebesar $-0,21 \%$ dan nilai maksimum sebesar $2,33 \%$. Nilai minimum negatif, menunjukkan selisih atau hasil pengurangan antara kontribusi peserta dengan beban asuransi yang bernilai negatif. Jika hasil pengurangan tersebut bernilai negatif maka perusahaan sudah dipastikan mengalami defisit underwriting.

Berdasarkan Tabel 4.2 variabel klaim memiliki nilai rata-rata sebesar 9,32\% dan deviasi standar sebesar 27,86\%. Nilai deviasi standar yang lebih besar dari nilai rata-rata menunjukan bahwa klaim perusahaan asuransi umum syariah dan unit usaha syariah sangat bervariasi. Nilai minimumnya sebesar $-87,69 \%$ dan nilai maksimum sebesar $65,82 \%$. Nilai minimum negatif yang menunjukkan bahwa klaim merupakan pengurang dana 
tabarru', bisa dikatakan ketika nilai klaim rendah diikuti dengan peningkatan pada dana tabarru' sehingga menyebabkan surplus pada dana tabarru'.

Berdasarkan Tabel 4.2 variabel retakaful memiliki nilai rata-rata sebesar $-12,10 \%$ dan nilai deviasi standar sebesar $37,24 \%$. Nilai deviasi standar yang lebih besar dari nilai rata-rata menunjukan bahwa retakaful perusahaan asuransi umum syariah dan unit usaha syariah sangat bervariasi. Nilai minimumnya sebesar $\quad-184.75 \%$ dan nilai maksimumnya sebesar $52,62 \%$. Nilai minimum negatif menunjukkan bahwa tingkat pembayaran retakaful rendah, sehingga dapat menambah proporsi cadangan klaim dan porsi untuk investasi. Selain itu, ketika nilai retakaful rendah, maka dapat menyebabkan surplus pada dana tabarru'.

Berdasarkan Tabel 4.2 variabel hasil investasi memiliki nilai rata-rata sebesar $1,69 \%$ dan nilai deviasi standar sebesar $5,07 \%$. Nilai deviasi standar yang lebih besar dari nilai rata-rata menunjukan bahwa hasil investasi perusahaan asuransi umum syariah dan unit usaha syariah sangat bervariasi. Nilai minimumnya sebesar $-28,53 \%$ dan nilai maksimumnya sebesar $11,14 \%$. Nilai minimum negatif menunjukkan hasil yang diperoleh dari dana peserta berupa dana tabarru' dan tabungan yang dikelola oleh perusahaan asuransi mengalami penurunan. Hasil investasi yang rendah akan mengakibatkan berkurangnya saldo dana peserta. Ketika hasil investasi mengalami penurunan maka dana tabarru' juga semakin menurun, dan pada saat dana tabarru' lebih kecil dari beban asuransi maka akan terjadi defisit pada dana tabarru'.

Berdasarkan Tabel 4.2 variabel kontribusi peserta memiliki nilai rata-rata sebesar Rp 1,52 juta dan nilai deviasi standar sebesar Rp 17,77 milyar. Nilai deviasi standar yang lebih besar dari nilai rata-rata menunjukan bahwa kontribusi peserta perusahaan asuransi umum syariah dan unit usaha syariah sangat bervariasi. Nilai minimumnya sebesar $\mathrm{Rp}$ -6,32 milyar dan nilai maksimumnya sebesar Rp 60,91 milyar. Nilai minimum negatif menunjukkan bahwa dana peserta perusahaan asuransi mengalami penurunan. Dana peserta yang merupakan hak peserta akan dilaporkan sebagai pengurang surplus dana tabarru'. Ketika terjadi defisit underwriting maka pengelola harus melakukan peminjaman terlebih dahulu (qardhul hasan). Pengembalian pinjaman qard tersebut harus berasal dari surplus underwriting dana tabarru' yang akan datang.

\section{Hasil Uji Normalitas Data}

Tabel 4.3 Hasil Uji

Kolmogorov-Smirnov Normalitas Data

\begin{tabular}{lcc}
\hline \multicolumn{1}{c}{ Variabel } & $\begin{array}{c}\text { Kolmogorov-S } \\
\text { mirnov }\end{array}$ & $\boldsymbol{\rho}$-value \\
\hline SDUT & 0,263 & 0,000 \\
Klaim & 0,120 & 0,071 \\
Retakaful & 0,130 & 0,033 \\
Hasil investasi & 0,330 & 0,000 \\
Kontribusi & 0,189 & 0,000 \\
peserta & & \\
\hline
\end{tabular}

Sumber : data diolah

Hasil uji normalitas data dengan menggunakan uji Kolmogorov-Smirnov yang disajikan pada Tabel 4.3 menunjukkan bahwa data memiliki $\rho$-value nol $(0,001)$ yang berarti nilai $\rho$-value lebih kecil dari $\alpha(5 \%)$ sehingga $\mathrm{H}_{0}$ ditolak. Hal ini berarti bahwa data tersebut tidak berdistribusi normal dan 


\section{JoPBA}

diperlukan perbaikan. Perbaikan data dilakukan dengan standarisasi, yaitu membagi nilai variabel dengan nilai rata-rata, nilai maksimum, dan nilai minimumnya. Setelah dilakukan standarisasi, data masih memiliki nilai $\rho$-value yang lebih kecil dari $\alpha(5 \%)$ sehingga $\mathrm{H}_{0}$ ditolak yang berarti data tersebut masih tidak berdistribusi normal. Langkah selanjutnya dengan membuang outliers atau nilai yang dianggap paling ekstrim. Setelah membuang nilai yang dianggap paling ekstrim, data masih memiliki nilai $\rho$-value yang lebih kecil dari $\alpha \quad(5 \%)$ sehingga data tidak berdistribusi normal. Langkah selanjutnya yaitu dengan menggunakan Central Limit Theorem yang menyebutkan bahwa data yang lebih dari 30 dapat dikatakan berdistribusi normal. Setelah data diasumsikan berdistribusi normal, maka dapat dilanjutkan ke langkah berikutnya yaitu dengan melakukan analisis regresi linear berganda.

\section{Hasil Uji Analisis Regresi Linear Berganda}

Tabel 4.4 Hasil Uji Analisis Regresi Linear Berganda

\begin{tabular}{lcccccc}
\hline $\begin{array}{l}\text { Variabel } \\
\text { Independe } \\
\quad \text { n }\end{array}$ & $\begin{array}{c}\text { Pred } \\
\text { iksi }\end{array}$ & $\begin{array}{c}\text { Koefi } \\
\text { sien }\end{array}$ & $\begin{array}{c}\text { t-hit } \\
\text { ung }\end{array}$ & $\begin{array}{c}\boldsymbol{\rho} \text {-v } \\
\text { alu } \\
\boldsymbol{e}\end{array}$ & $\begin{array}{c}\text { F-hit } \\
\mathbf{u n g} \\
(\boldsymbol{\rho} \text {-val } \\
\mathbf{u e})\end{array}$ & $\begin{array}{c}\mathbf{R} \\
\mathbf{( R}^{\mathbf{2}}\end{array}$ \\
\hline Konstanta & & 0,211 & & & & \\
Klaim & & $-0,00$ & $-8,74$ & 0,0 & & \\
& - & 7 & 9 & 00 & & \\
Retakaful & - & 7,431 & 0,11 & 0,4 & 25,46 & 0,7 \\
& & & 7 & 54 & 5 & 28 \\
Hasil & + & $-0,01$ & $-1,22$ & 0,1 & & \\
investasi & & 0 & 5 & 14 & & \\
$\begin{array}{l}\text { Kontribusi } \\
\text { peserta }\end{array}$ & + & 6,010 & 5,19 & 0,0 & & \\
\hline
\end{tabular}

ISSN-E : XXX

ISSN-P : XXX
Hasil analisis regresi linear berganda disajikan dalam Tabel 4.4. Berdasarkan hasil analisis regresi linear berganda yang disajikan dalam Tabel 4.4, maka diperoleh persamaan model regresi sebagai berikut:

$Y_{i t}=0,211-0,007 K_{i t}+7,431 R_{i t}-0,010 I_{i t}$ $+6,010 K n_{i t}$

\section{Hasil Uji Asumsi Klasik}

\section{Uji Normalitas Model}

Uji normalitas model bertujuan untuk menguji apakah residual pada model yang diestimasi berdistribusi normal atau tidak. Hasil uji normalitas model dengan menggunakan uji Kolmogorov-Smirnov menunjukkan bahwa residual memiliki nilai $\rho$-value 0,602 yang berarti lebih besar dari $\alpha(5 \%)$, sehingga $\mathrm{H}_{0}$ diterima. Hal ini berarti residual pada model berdistribusi normal.

\section{Uji Multikolinearitas}

Tabel 4.5 Hasil Uji Multikolinearitas

\begin{tabular}{cccc}
\hline $\begin{array}{c}\text { Variabel } \\
\text { Independen }\end{array}$ & $\begin{array}{l}\text { Toler } \\
\text { ance }\end{array}$ & VIF & Keterangan \\
\end{tabular}

\begin{tabular}{|c|c|c|c|}
\hline Klaim & 0,880 & 1,137 & $\begin{array}{c}\text { Tidak terjadi } \\
\text { multikolinearitas }\end{array}$ \\
\hline Retakaful & 0,867 & 1,153 & $\begin{array}{c}\text { Tidak terjadi } \\
\text { multikolinearitas }\end{array}$ \\
\hline Hasil investasi & 0,938 & 1,067 & $\begin{array}{c}\text { Tidak terjadi } \\
\text { multikolinearitas }\end{array}$ \\
\hline $\begin{array}{l}\text { Kontribusi } \\
\text { peserta }\end{array}$ & 0,953 & 1,050 & $\begin{array}{c}\text { Tidak terjadi } \\
\text { multikolinearitas }\end{array}$ \\
\hline
\end{tabular}

Uji multikolinearitas bertujuan untuk menguji apakah model regresi ditemukan adanya korelasi antar variabel independen. Untuk mendeteksi adanya multikolinearitas dalam sebuah model regresi dapat dilihat dari Variance Inflation Factor (VIF) dan Tolerance. Jika nilai VIF $<10$ atau Tolerance $>0,10$ 
maka tidak terjadi multikolinearitas. Hasil uji multikolinearitas disajikan dalam Tabel 4.5. Berdasarkan Tabel 4.5 seluruh variabel independen memiliki VIF $<10$ dan nilai Tolerance $>0,10$. Hal ini berarti hasil uji analisis regresi linear berganda tidak terjadi multikolinearitas.

\section{Uji Heteroskedastisitas}

Tabel 4.6 Hasil Uji Glejser

\begin{tabular}{lcc}
\hline $\begin{array}{c}\text { Variabel } \\
\text { Independen }\end{array}$ & p-value & Keterangan \\
\hline Klaim & 0,274 & $\begin{array}{c}\text { Tidak terjadi } \\
\text { heteroskedastisitas }\end{array}$ \\
Retakaful & 0,570 & $\begin{array}{c}\text { Tidak terjadi } \\
\text { heteroskedastisitas }\end{array}$ \\
$\begin{array}{l}\text { Hasil } \\
\text { investasi }\end{array}$ & 0,794 & $\begin{array}{c}\text { Tidak terjadi } \\
\text { heteroskedastisitas }\end{array}$ \\
$\begin{array}{l}\text { Kontribusi } \\
\text { peserta }\end{array}$ & 0,808 & $\begin{array}{c}\text { Tidak Terjadi } \\
\text { heteroskedastisitas }\end{array}$
\end{tabular}

Berdasarkan hasil uji heteroskedastisitas yang dilakukan dengan menggunakan uji Glejser yang disajikan dalam Tabel 4.6 menunjukkan bahwa $\rho$-value $>0,05$ sehingga $\mathrm{H}_{0}$ diterima. Hal ini berarti model regresi tidak terjadi heteroskedastisitas.

\section{Uji Autokorelasi}

Pengujian autokorelasi dilakukan dengan menggunakan uji Durbin-Watson. Hasil uji Durbin-Watson disajikan dalam Tabel 4.7. Berdasarkan Tabel 4.7 model regresi mengandung autokorelasi positif. Karena nilai DW $(1,262)$ lebih kecil dari dL $(1,3779)$. Hal ini menunjukkan bahwa pada model regresi terjadi autokorelasi dan harus dilakukan perbaikan. Sebagai perbaikan dari adanya autokorelasi, dilakukan uji Cochrane Orcutt. Adapun hasil uji dengan metode Cochrane Orcutt disajikan dalam Tabel 4.7. Hasil perbaikan menunjukkan nilai DW $(2,067)$ berada diantara nilai dU dan 4-dU (2,2786) yang berarti $\mathrm{H}_{0}$ diterima. Artinya hasil uji perbaikan dengan metode Cochrane Orcutt menunjukkan bahwa model regresi tidak megandung autokorelasi.

\section{Hasil Uji Hipotesis}

Tabel 4.8 Hasil Uji t

\begin{tabular}{|c|c|c|}
\hline $\begin{array}{c}\text { Variabel } \\
\text { Independen }\end{array}$ & $\rho$-value & $\begin{array}{c}\text { Keteran } \\
\text { gan }\end{array}$ \\
\hline Klaim & 0,000 & $\begin{array}{c}\mathrm{H}_{0} \\
\text { ditolak }\end{array}$ \\
\hline Retakaful & 0,454 & $\begin{array}{c}\mathrm{H}_{0} \\
\text { diterima }\end{array}$ \\
\hline $\begin{array}{l}\text { Hasil } \\
\text { investasi }\end{array}$ & 0,114 & $\begin{array}{c}\mathrm{H}_{0} \\
\text { diterima }\end{array}$ \\
\hline $\begin{array}{l}\text { Kontribusi } \\
\text { peserta }\end{array}$ & 0,000 & $\begin{array}{c}\mathrm{H}_{0} \\
\text { ditolak }\end{array}$ \\
\hline
\end{tabular}

Pengujian hipotesis dalam penelitian ini menggunakan uji t. Hasil uji t disajikan dalam Tabel 4.8. Berdasarkan Tabel 4.8 dapat diketahui pengaruh masing-masing variabel independen terhadap variabel dependen yaitu sebagai berikut :

1) Hasil Uji Hipotesis Variabel Klaim terhadap Surplus (Defisit) Underwriting Dana Tabarru'

Uji hipotesis secara parsial menghasilkan nilai $\rho$-value variabel klaim sebesar 0,000. Hal ini menunjukkan bahwa nilai $\rho$-value lebih kecil dari nilai $\alpha$ (5\%), sehingga dapat dinyatakan bahwa $\mathrm{H}_{0}$ ditolak. Artinya variabel klaim berpengaruh terhadap surplus (defisit) underwriting dana tabarru'. 
2) Hasil Uji Hipotesis Variabel Retakaful terhadap Surplus (Defisit) Underwriting Dana Tabarru'

Uji hipotesis secara parsial menghasilkan nilai $\rho$-value variabel retakaful sebesar 0,454 . Hal ini menunjukkan bahwa nilai $\rho$-value lebih besar dari nilai $\alpha$ $(5 \%)$, sehingga dapat dinyatakan bahwa $\mathrm{H}_{0}$ diterima. Artinya variabel retakaful tidak berpengaruh terhadap surplus (defisit) underwriting dana tabarru'.

3) Hasil Uji Hipotesis Variabel Hasil Investasi terhadap Surplus (Defisit) Underwriting Dana Tabarru'

Uji hipotesis secara parsial menghasilkan nilai $\rho$-value variabel hasil investasi sebesar 0,114 Hal ini menunjukkan bahwa nilai $\rho$-value lebih besar dari nilai $\alpha \quad(5 \%)$, sehingga dapat dinyatakan bahwa $\mathrm{H}_{0}$ diterima. Artinya variabel hasil investasi tidak berpengaruh terhadap surplus (defisit) underwriting dana tabarru'.

4) Hasil Uji Hipotesis Variabel Kontribusi Peserta terhadap Surplus (Defisit) Underwriting Dana Tabarru'

Uji hipotesis secara parsial menghasilkan nilai $\rho$-value variabel kontribusi peserta sebesar 0,000 . Hal ini menunjukkan bahwa nilai $\rho$-value lebih kecil dari nilai a (5\%), sehingga dapat dinyatakan bahwa $\mathrm{H}_{0}$ ditolak. Artinya variabel kontribusi peserta berpengaruh terhadap surplus (defisit) underwriting dana tabarru'.

Berdasarkan hasil uji hipotesis dapat dinyatakan bahwa dua variabel independen (klaim dan kontribusi peserta) berpengaruh terhadap surplus (defisit) underwriting dana tabarru' pada perusahaan asuransi umum syariah dan unit usaha syariah perusahaan asuransi umum yang terdaftar di Otoritas Jasa Keuangan. Hal ini menunjukkan bahwa surplus (defisit) underwriting dana tabarru' dapat dipengarungi oleh kedua variabel tersebut. Sedangkan variabel retakaful dan hasil investasi merupakan variabel yang tidak berpengaruh terhadap surplus (defisit) underwriting dana tabarru'. Dengan demikian dapat dinyatakan bahwa tidak terdapat pengaruh antara retakaful dan hasi; investasi dengan surplus (defisit) underwriting dana tabarru'.

\section{Pembahasan}

Hasil penelitian menunjukkan bahwa variabel klaim secara parsial berpengaruh negatif terhadap surplus (defisit) underwriting dana tabarru' pada perusahaan asuransi umum syariah dan unit usaha syariah perusahaan asuransi umum yang terdaftar di Otoritas Jasa Keuangan. Jadi, klaim dapat dikatakan sebagai faktor yang dapat memengaruhi surplus (defisit) underwriting dana tabarru' pada perusahaan asuransi umum syarian dan unit usaha syariah perusahaan asuransi umum. Berdasarkan tinjauan teori, klaim bukan merupakan beban pengelola tetapi merupakan beban asuransi atau underwriting yang diambil dari dana peserta. Perbedaan ini disebabkan oleh konsep dana tabarru' dan pembagian risiko (sharing of risk) yang digunakan oleh perusahaan asuransi syariah. Menurut Sula (2004:260) klaim merupakan hak peserta dan dananya diambil dari dana tabarru'. Klaim merupakan pengurang dari dana tabarru'. Sehingga ketika jumlah klaim meningkat maka surplus underwriting menurun atau terjadi defisit underwriting dan begitu sebaliknya. Ketika jumlah klaim sedikit 


\section{$\mathrm{J} \underline{\underline{\underline{P B A}}}$}

akan meningkatkan surplus underwriting dana tabarru'.

Hal ini sejalan dengan hasil penelitian Damayanti (2016) dan Alifianingrum (2016) yang menyatakan bahwa klaim berpengaruh negatif dan signifikan terhadap surplus underwriting. Pengaruh negatif menunjukkan hubungan yang berbanding terbalik antara klaim dan surplus underwrting. Hal tersebut menjelaskan bahwa klaim merupakan pengurang dari dana tabarru', sedangkan surplus underwriting terjadi ketika dana tabarru' nilainya lebih besar daripada beban asuransi yang ditanggung.

\section{Pengaruh Retakaful Terhadap Underwriting Pengelolaan Dana Tabarru'}

Hasil penelitian menunjukkan bahwa variabel retakaful secara parsial tidak berpengaruh negatif terhadap surplus (defisit) underwriting dana tabarru' pada perusahaan asuransi umum syariah dan unit usaha syariah perusahaan asuransi umum yang terdaftar di Otoritas Jasa Keuangan. Jadi, retakaful bukan sebagai faktor yang dapat memengaruhi surplus (defisit) underwriting dana tabarru' pada perusahaan asuransi umum syarian dan unit usaha syariah perusahaan asuransi umum. Kegiatan retakaful dilakukan pada saat perusahaan asuransi tidak mampu menanggulangi sendiri risiko yang muncul. Semakin besar kontribusi retakaful yang dibayarkan, maka semakin tinggi risiko yang melekat pada objek yang diasuransikan, sehingga membutuhkan dana tabarru' yang semakin besar pula. Tingginya frekuensi pembayaran retakaful akan mengurangi proporsi cadangan klaim dan porsi untuk investasi. Hal ini dikhawatirkan memengaruhi menurunnya atau bahkan tidak adanya surplus underwriting (Puspitasari, 2015). Surplus underwriting yang rendah akan berpengaruh pada
ISSN-E : XXX

ISSN-P : XXX

jumlah pengembalian surplus dana tabarru'. Namun, penelitian ini tidak menemukan bukti mengenai hal tersebut.

Hal ini dapat ditinjau dari konsep asuransi syariah bahwa pada dasarnya retakaful (pertanggungan ulang) terjadi apabila perusahaan asuransi memiliki nasabah atau peserta dengan risiko yang sangat tinggi dan tidak mampu menanggulangi sendiri risiko sehingga perusahaan asuransi akan membagi seluruh atau sebagian risiko dari pertanggungan yang mampu dilakukan kepada pihak lain yang dalam hal ini adalah perusahaan retakaful. Apabila perusahaan asuransi umum syariah yang memiliki peserta dengan tingkat risiko yang dianggap tidak terlalu besar dan perusahaan tersebut masih mampu menanggulanginya sendiri, maka perusahaan asuransi umum syariah tidak perlu melakukan retakaful (pertanggungan ulang) kepada pihak lain. Oleh karena itu, perusahaan asuransi umum syariah sedikit atau tidak seterusnya melakukan retakaful.

\section{Pengaruh Hasil Investasi Terhadap Underwriting Pengelolaan Dana Tabarru'}

Hasil penelitian menunjukkan bahwa variabel hasil investasi secara parsial tidak berpengaruh positif terhadap surplus (defisit) underwriting dana tabarru' pada perusahaan asuransi umum syariah dan unit usaha syariah perusahaan asuransi umum yang terdaftar di Otoritas Jasa Keuangan. Jadi, hasil investasi bukan sebagai faktor yang memengaruhi surplus (defisit) underwriting dana tabarru' pada perusahaan asuransi umum syarian dan unit usaha syariah perusahaan asuransi umum. Investasi dalam Islam berarti menanamkan modal pada sektor tertentu yaitu sektor keuangan atau sektor riil pada periode tertentu untuk mendapatkan keuntungan yang 
diharapkan (expected return) dari hasil investasi. Hasil investasi merupakan hasil yang diperoleh dari dana peserta berupa dana tabarru' dan tabungan yang dikelola oleh perusahaan asuransi sebagai pengelola. Dalam hal ini, peserta atau nasabah adalah pemilik dana dan perusahaan asuransi adalah mudharib (pengelola dana). Hasil investasi dana peserta ini akan menambah saldo Dana Peserta. Hasil investasi ini juga merupakan jumlah bruto sebelum dikeluarkannya hak pengelola atas hasil investasi tersebut. Hak pengelola atas hasil investasi diukur berdasarkan nisbah bagi hasil yang menggunakan akad mudharabah, yang telah disepakati dan diakui sebagai pengurang hasil investasi.

Dana yang dikumpulkan peserta yang merupakan dana tabarru' tersebut oleh perusahaan asuransi diinvestasikan sesuai dengan prinsip syariah. Ketika perusahaan mengalami peningkatan hasil investasi maka dana tabarru' juga semakin meningkat, dan pada saat dana tabarru' lebih besar dari beban asuransi maka terjadi surplus underwriting. Pada saat dana tabarru' lebih kecil dari beban asuransi maka terjadi defisit underwriting (Sula, 2014). Namun, penelitian ini tidak menemukan bukti mengenai hal tersebut.

Hal ini dapat ditinjau dari beberapa aspek, seperti dikarenakan investasi yang kurang konservatif, kompetisi yang ketat dalam segmen retail, dan menurunnya bisnis surety bond perusahaan (sindonews.com). Menurut Ketua Umum Asosiasi Asuransi Syariah Indonesia (AASI) A. Syaroni bahwa, masih meruginya hasil investasi disebabkan iklim investasi dan kondisi makro ekonomi yang kurang baik. Selain itu, pilihan instrumen investasi di asuransi syariah yang jumlahnya masih lebih sedikit dari asuransi konvensional. Industri asuransi syariah umumnya mengalokasikan dana investasi $30 \%$ di sukuk. Namun, pergerakan sukuk saat ini kurang baik. Kewajiban perusahaan asuransi untuk menginvestasikan dana di sukuk membuat perusahaan asuransi syariah merugi dalam berinvestasi. Oleh karena itu, hasil investasi tidak dapat dikatakan sebagai faktor yang dapat memengaruhi surplus (defisit) underwriting dana tabarru'.

Penelitian ini konsisten dengan hasil penelitian Damayanti (2016) yang menyatakan bahwa hasil investasi tidak berpengaruh signifikan terhadap surplus underwriting dana tabarru'. Ketidaksignifikan hasil investasi dapat dilihat dari perkembangan hasil investasi dan surplus underwriting. Pada periode tertentu surplus underwriting mengalami penurunan yang berbeda-beda. Meskipun hasil investasi pada periode tertentu mengalami peningkatan, namun belum tentu memengaruhi surplus underwriting. Hal ini menunjukkan bahwa penurunan nilai surplus underwriting terjadi karena beberapa perusahaan mengalami defisit underwriting pada periode tahun tertentu. Tingginya nilai defisit underwriting tersebut disebabkan oleh meningkatnya beban klaim, beban penyisihan teknis, dan perubahan kontribusi yang belum menjadi hak yang nilainya berubah menjadi negatif dari tahun sebelumnya.

Berbanding terbalik dengan hasil penelitian Alifianingrum (2016) yang menyatakan bahwa hasil investasi berpengaruh positif dan signifikan terhadap surplus underwriting dana tabarru'. Sedangkan hasil penelitian Fadlullah (2014) berbeda dengan penelitian-penelitian sebelumnya, yang menyatakan bahwa hasil investasi berpengaruh secara signifikan dan positif terhadap cadangan dana tabarru'. Jika hasil investasi mengalami kenaikan, maka cadangan dana tabarru' akan mengalami peningkatan pula. Hasil investasi berpengaruh secara signifikan 


\section{$\mathrm{J} \underline{\underline{\underline{P B A}}}$}

positif artinya terjadi hubungan positif antara hasil investasi dengan cadangan dana tabarru'. Semakin tinggi hasil investasi maka semakin meningkat cadangan dana tabarru'.

\section{Pengaruh Kontribusi Peserta Terhadap Underwriting Pengelolaan Dana Tabarru'}

Hasil penelitian menunjukkan bahwa variabel kontribusi peserta secara parsial berpengaruh positif terhadap surplus (defisit) underwriting dana tabarru' pada perusahaan asuransi umum syariah dan unit usaha syariah perusahaan asuransi umum yang terdaftar di Otoritas Jasa Keuangan. Jadi, kontribusi peserta merupakan faktor yang dapat memengaruhi surplus (defisit) underwriting dana tabarru' pada perusahaan asuransi umum syarian dan unit usaha syariah perusahaan asuransi umum.

Berdasarkan tinjauan teori, kontribusi peserta diakui sebagai bagian dari dana tabarru' dalam dana peserta. Dana peserta tersebut terdiri dari dana tabarru', dana investasi, hasil investasi, dan cadangan surplus underwriting. Bagian yang menjadi hak peserta maupun penelola akan dilaporkan sebagai pengurang surplus dana tabarru' dalam laporan perubahan dana tabarru'. Jika terjadi defisit dalam underwriting, maka penelola harus meminjamkan terlebih dahulu sebagai pinjaman qardh dan akan dilaporkan sebagai kewajiban di neraca serta pendapatan dalam laporan surplus dan defisit dana tabarru'. Pengembalian pinjaman qardh tersebut harus berasal dari surplus dana tabarru' yang akan datang. Ketika kontribusi meningkat maka klaim akan rendah, dan ketika jumlah klaim sedikit maka akan meningkatkan surplus underwriting.

Penelitian ini konsisten dengan hasil penelitian Damayanti (2016) yang menyatakan bahwa kontribusi peserta secara parsial berpengaruh positif dan signifikan terhadap surplus underwriting. Ketika kontribusi peserta meningkat maka surplus underwriting juga mengalami peningkatan. kontribusi merupakan kewajiban peserta takaful yang muncul dari perjanjian antara peserta dan pengelola. Dana kontribusi pserta dikelola oleh perusahaan asuransi syariah dalam bentuk dana tabarru' dan dana tesebut digunakan untuk membayar klaim kepada peserta atau nasabah asuransi apabila terjadi musibah di masa yang akan datang. Selain itu, penelitian ini juga konsisten dengan hasil penelitian Alifianingrum (2016) yang menyatakan bahwa kontribusi neto berpengaruh positif dan signifikan terhadap surplus underwriting dana tabarru'.

\section{KESIMPULAN DAN SARAN}

Penelitian ini bertujuan untuk menganalisis faktor-faktor yang mempengaruhi surplus (defisit) underwriting dana tabarru' pada perusahaan asuransi umum syariah dan unit usaha syariah perusahaan asuransi umum di Indonesia. Hasil penelitian menunjukkan bahwa klaim berpengaruh negatif dan signifikan terhadap surplus (defisit) underwriting dana tabarru' pada perusahaan asuransi umum syariah dan unit usaha syariah perusahaan asuransi umum di Indonesia. Hasil investasi dan retakaful tidak berpengaruh signifikan terhadap surplus (defisit) underwriting dana tabarru' pada perusahaan asuransi umum syariah dan unit usaha syariah perusahaan asuransi umum di Indonesia. Sedangkan kontribusi peserta berpengaruh positif dan signifikan terhadap surplus (defisit) underwriting dana tabarru' pada perusahaan asuransi umum syariah dan unit usaha syariah perusahaan asuransi umum di Indonesia. 
Terdapat beberapa saran yang diajukan dalam penelitian ini. Pertama, bagi Perusahaan asuransi umum syariah dan unit usaha syariah perusahaan asuransi umum dalam pengelolaan dana tabarru' juga harus memerhatikan hal apa saja yang dapat mendatangkan keuntungan atau kerugian bagi perusahaan. Jika perusahaan asuransi umum syariah dan unit usaha syariah perusahaan asuransi umum bersikap hati-hati dan melakukan underwriting yang baik dalam pengelolaan dana tabarru', kemungkinan klaim yang terjadi akan berkurang dan berakibat pada surplus underwriting dana tabarru'. Namun, jika perusahaan tidak memerhatikan underwriting dengan baik maka kemungkinan besar dana tabarru' akan mengalami defisit underwriting. Kedua, bagi peneliti selanjutnya yang akan melakukan penelitian serupa dengan penelitian ini disarankan untuk melakukan perbaikan dengan menambah jumlah tahun pengamatan dan Menguji kembali faktor-faktor yang memengaruhi surplus (defisit) underwriting dana tabarru' dengan menggunakan sampel penelitian yang terpisah antara perusahaan asuransi umum syariah dan unit usaha syariah perusahaan asuransi umum. 


\section{PUSTAKA ACUAN}

Alifianingrum, R. 2016. Analisis Pengaruh Kontribusi Neto, Beban Klaim, dan Hasil Investasi Terhadap Surplus Underwriting Dana Tabarru' Pada Perusahaan Asuransi Jiwa Syariah di Indonesia Tahun 2011-2015. Skripsi. Surabaya: Universitas Airlangga.

Arofah, Siti U. 2018. Determinan Proporsi Dana Tabarru' Pada Perusahaan Asuransi Jiwa Syariah dan Unit Syariah Perusahaan Asuransi Jiwa Di Indonesia. Skripsi. Jember: Universitas Jember.

AlNemer, H.A. 2015. An Empirical Study of Takaful Participants Perception of The Distribution of The Underwriting Surplus and Its Impact on Participants Behaviour. International Journal of Economics, Commerce and Management. Vol 3 (4):1-16.

Bayinah, Ai Nur., Mulyati, S., Mardian, S., \& Maulidha, E. 2017. Akuntansi Asuransi Syariah. Jakarta: Salemba Empat.

Dewan Syariah Nasional. Fatwa DSN MUI No. 53/DSN-MUI/III/2006 Tentang Tabarru' Pada Asuransi Syariah. http://www.dsnmui.or.id/index.php?page=fatwa. [Diakses pada tanggal 27 September 2018].

Dewan Syariah Nasional. Fatwa DSN MUI No. 21/DSN-MUI/X/2001 Tentang Pedoman Umum Asuransi Syariah. http://www.dsnmui.or.id/index.php?page=fatwa. [Diakses pada tanggal 27 September 2018].

Damayanti, F.E. 2016. Pengaruh Kontribusi Peserta, Kalim, dan Hasil Investasi Terhadap Surplus Underwriting Asuransi Umum Syariah di Indonesia. Skripsi. Surabaya: Universitas Airlangga.

Gujarati, D.N \& Porter, D.C. 2010. Basic Econometrics. Fifth Edition. New York: McGraw-Hill Education. Terjemahan oleh Eugenia M., Sita WW. dan Carlos M. 2015. Dasar-dasar Ekonometrika. Edisi 5. Jakarta: Salemba Empat.

Ghozali, I. 2007. Aplikasi Analisis Multivariate dengan Program SPSS. Semarang: Badan Penerbit Universitas Diponegoro.

Haidar, M.I. 2015. Analisis Pengakuan, Pengukuran, dan Penyajian Surplus/Defisit Underwriting Dana Tabarru' Berdasarkan PSAK 108 Pada PT. Prudential Life Assurance. Skripsi. Semarang: Universitas Islam Negeri Walisongo.

Ibrahim, A.B., Hamdi Mohd Ali, A.F., Elias, Mohd Hafizal., Lotfi, Wan Ahmad. 2015. Distribution of Underwriting Surplus and Investment Profit from Tabarru' Fund: Shariah Contracts Applied and Current Market Practice. Procceding of Sydney International Business Research Conference 2015 
University of Western Sydney Campbelltown Australia 17-19 April 2015. ISSBN 978-0-9942714-0-2.

Manan, A. 2012. Hukum Ekonomi Syariah. Jakarta: Kencana.

Noordin, K. 2013. The Management of Underwriting Surplus by Takaful Operators in Malaysia. Department of Shariah and Management. Malaysia: Academy of Islamic Studies University.

Otoritas Jasa Keuangan. Statistik Bulanan IKNB Syariah Juli 2018. http://www.ojk.go.id/id/kanal/syariah/data-dan-statistik/iknb-syariah/default.as px. [Diakses pada tanggal 25 September 2018].

Puspitasari, N. 2011. Shari'a Split Fund Theory Sebagai Refleksi Praktik Pemisahan Dana Bisnis Asuransi Umum Syariah. Disertasi. Malang: Universitas Brawijaya.

Puspitasari, N. 2012. Model Proporsi Tabarru' dan Ujrah Pada Bisnis Asuransi Umum Syariah di Indonesia. Jurnal Akuntansi dan Keuangan Indonesia.Vol 9 No.1:43-55

Puspitasari, N. 2015. Manajemen Asuransi Syariah. Yogyakarta: UII Press.

Puspitasari, N. 2016. Determinan Proporsi Dana Tabarru' Pada Lembaga Keuangan Asuransi Syariah. Jurnal Akuntansi dan Keuangan Indonesia. Vol 13 No. 2:160-173.

Puspitasari, N. 2018. Keuangan Islam: Teori dan Praktik. Yogyakarta: UII Press.

Peraturan Menteri Keuangan. PMK No. 18/PMK.010/2010 Tentang Penerapan Prinsip Dasar Penyelenggaraan Usaha Asuransi dan Usaha Reasuransi Dengan Prinsip Syariah. https://www.ojk.go.id/kanal/iknb/regulasi/asuransi/peraturan-keputusan-menter i/pages/peraturan-menteri-keuangan-nomor-18-pmk-010-2010-tentang-prinsipdasar-penyelenggaraan-usaha-asuransi-dan-usaha-reasura.aspx. [Diakses pada tanggal 27 September 2018].

Rodoni, A. 2015. Asuransi dan Pegadaian Syariah. Jakarta: Mitra Wacana Media.

Sula, M.S. 2004. Asuransi Syariah (Life and General): Konsep dan Sistem Operasional. Jakarta: Gema Insani. 